\title{
The Characteristic of the Process of Students' Metacognition in Solving Calculus Problems
}

\author{
Dwi Purnomo ${ }^{1}$, Toto Nusantara ${ }^{2}$, Subanji $^{2} \&$ Swasono Rahardjo ${ }^{2}$ \\ ${ }^{1}$ Department of Mathematics Education of Teachers' Training College, Budi Utomo Malang, Indonesia \\ ${ }^{2}$ Department of Mathematics Education, State University of Malang, Indonesia \\ Correspondence: Dwi Purnomo, Department of Mathematics Education of Teachers' Training College, Jalan \\ Simpang Arjuno No. 14, Budi Utomo Malang, Indonesia. Tel: 62-81-2522-8614, 62-341-802-929. E-mail: \\ dwi2purnomo@yahoo.co.id
}

Received: May 17, 2016

doi:10.5539/ies.v10n5p13
Accepted: December 14, 2016 Online Published: April 29, 2017

URL: https://doi.org/10.5539/ies.v10n5p13

\begin{abstract}
This article is the result of research aims to describe the patterns and characteristics of the process of metacognition student of mathematics in solving calculus problems. Description was done by looking at changes in awareness, evaluation, and regulation as components of metacognition. The changes in components of metacognition seen by the emergence of indicators for each indicator were described in descriptors. To see the changes, the researcher used the instrument consisting of calculus problems, metacognition questionnaires, observation sheet, and interviews. Researcher gave calculus to 23 students who followed the course of differential calculus. The research data were in the form of the works of the students, transcript think-aloud, metacognition questionnaire results, observations using the observation sheet, and a transcript of the interview. Based on research data obtained, the research subjects were categorized in the high-ability students, medium, and low. Data were analyzed using constant comparison method of Glaser and Strauss. Based on data, analysis can be concluded that the pattern and characteristics of the change process awareness, evaluation and regulation mathematic students in solving calculus problems can be distinguished in the process of metacognition complete with the order, complete metacognition was not with the order, and metacognition incomplete.
\end{abstract}

Keywords: metacognition, awareness, evaluation, regulation, calculus problem

\section{Introduction}

Mathematics as a part of the instruction at school has direct object and indirect object. Gagne (Soedjadi, 2000; Hudojo, 2008) states that mathematical direct object relates to fact, concept, operation, and principle. The fact is a convention or agreement used to make mathematical discussion go smoothly, such as symbol, notation. The symbol " 4 " has been understood as figure "four". If it is 4, people understand it is "four". On the other hand, if someone says the word "four", it is symbolized by "4". The concept is an abstract idea which can be used to classify a group of a certain objects. A concept in the field of mathematics is called mathematical concept. "Triangulation" is a name of an abstract concept. With a concept, a group of objects can be classified as an example or not. The concept has a closely related to definition. Definition is an utterance which limits a concept. With it, someone can make illustration, picture, or symbol of defined concept. So that, it is clearer what is meant by a certain concept. Mathematical operation is procedures and as a process to find out a certain result. If the concept is an association, the possible operations are union, section, difference, or complement. Besides on association, it is known as addition operation, difference, multiplication, and division. The principle is the relation between various complex mathematical principle objects and consists of some facts. The right value principle is the principle has two or more concepts and states the relation between those concepts. For instance, the result of multiple of the figures $\mathrm{p}$ and $\mathrm{q}$ is zero if and if only $\mathrm{p}=0$ or $\mathrm{q}=0$.

The mathematical indirect object relates to the ability of logical thinking, solve problem, analytical thinking, positive thinking towards mathematics, careful, diligent, discipline and the other cases implicitly will be obtained if someone learns mathematics. Based on the opinion of Gagne above, it can conclude that one of the objects learned in mathematics is a concept. Mathematical concept orientation can be done through instruction. Djamarah (2008) states that someone who has possesses concept can do abstracting so that he/she can translate and call awareness and form mentally representation. During understanding the concept, someone needs the 
ability and strategy or certain way. Duffin and Simpson (2000) states that the ability possessed by someone during understanding the concept is expected to be able to re-express something communicated to the source of study, and finally, when the concept has been mastered, the given problems can answered.

Polya (1988) mentions four steps in solving problem, i.e. understand the problem, plan the treatment, execute the plan, and review the treatment done. The steps expressed by Polya in solving problem are activities which can be during the instruction and indicator in determine instructional result completeness. According to Bloom taxonomy completeness of learning result is classified into the field of cognitive, affective, and psychomotor. Especially for the field of cognitive, Anderson \& Krathwohl (2001) improve into cognition process dimension and knowledge dimension. Cognition process consists of remembering, understanding, applying, analyzing, evaluating, and creating. But, knowledge consists of factual, conceptual, procedural and metacognition.

Metacognition comes from "meta" and "cognition". Meta is a Greek means after or behind. Cognition is a process of obtaining knowledge (Zahmeister \& Neyberg, 1982). During its process, metacognition can be related to the activities of problem solving, knowledge, cognition process and the strategy used during the instruction. The term of metacognition used for the first time by Flavell in 1976. According to him, metacognition consists of knowledge, experience and regulation which function as the important element and contribute the success of the problem solving.

The facts expressed by some high students during solving the problem that they often meet the failures. The failures were caused by the lack of the understanding of metacognition aspects, especially, which are related to the steps done to solve problem (Schoenfeld, 1992; Goos, 1995). As the improvement of the study, especially relates to the process of metacognition, it is found out that metacognition can assist one's thinking process more effectively and opened (Wilson \& Clarke, 2004). While Schoenfeld (1992) regards that the difficulty in solving problem is closely related to student's inability to observe and control the process of metacognition.

Some studies related to metacognition and problem solving has been done. Among of them are Desoete (2001), Lioe et al. (2003), Wilson and Clarke (2004), Cromley (2005), Efklides (2006), Lesh (2007), Panauorra (2009), Kuzle (2011), Molenar (2011), Karan and Irizary (2011), Magiera and Zawojewski (2011), In'am et al. (2012), Praba (2013), Zaenal and Tajudin (2013). The studies generally discuss the process metacognition in the subject of the study. However, it has not brought up the student's metacognition process characteristic in solving problem yet. Relating to the case, the researcher does the research to analyse and describes the mathematical student's metacognition process characteristic in solving calculus problems. The student's metacognition process characteristic described based on the process of awareness, evaluation, and regulation which are the components of metacognition.

\section{Theoretical Study}

\subsection{The Definition of Metacognition}

Friedrichs and Hoyt (1976) mention metacognition in term of metamemory. While Veenman (2012) describes metacognition as two main parts: the knowledge of metacognition and regulation or the observation of metacognition. The knowledge of metacognition is an interaction offering between someone's knowledge and the ability to do someone's assignments, characters of assignment, and the strategy which can be used to do the assignments. The regulation or metacognition observation is the activities relate to planning, monitoring, someone's evaluating, and the process of cognition to control the process. Metacognition as a process has four important aspects. According to Baker \& Brown (1984) those aspects are self-controlling, planning, evaluating, and monitoring. Wellman (1985) states that metacognition is as form of cognition or two or more thinking process which include the control of the cognition activity. Therefore, metacognition can be said as thinking of someone's thinking of him/her-self or someone's knowledge of his/her cognition.

Besides having four aspects, according to Schoenfeld (1992), metacognition is as the process of someone's thinking process of what he/she has thought and as the interaction between the three important aspects, namely the knowledge of thinking process, self-controlling, and intuition. The interaction is very important for the knowledge of cognition process can assist and control the cases around us and select the strategies to improve our next cognition ability. According to Schoenfeld, the process of metacognition includes the ability to ask a question, and answer the question about a case, topic and problem, time allocation used to learn a certain topic, strategy, method and tactic used, level being learn by the student, fault done by the student, and revise the next plan.

Livingstone (1997) defines metacognition as thinking about thinking. In the other word, metacognition is someone thinking ability about what is thought. So that, metacognition object is thinking process happened to 
someone. Biryukov (2003) says that metacognition is someone thinking hypothesis of what has been thought before and includes knowledge, skill and experience. Knowledge is awareness of what is known, skill in the form of awareness of something done, and experience is awareness of cognition ability possessed.

Davidson and Sternberg (1998) state that metacognition has an important functions and contributes the success of problem solving that enable someone to identify and work strategically. Matlin (1998) states that metacognition is knowledge relates to awareness and cognition process. Wellman (1985) states that metacognition is as a form of cognition, or two or more thinking process including controlling of cognition activity. Therefore, metacognition can be said as someone thinking of self-thinking or someone cognition of self-cognition.

Tan (2003) states that metacognition is thoughtfulness refers to think of self-thinking, self-checking, and information process and how to process information effectively. Lioe (2003) states that metacognition is someone awareness about cognition process and selfness to reach a certain goal. Metacognition appears in problem solving whose components are attitude, skill, concept, process, and metacognition.

Peirce (2003) defines metacognition generally and specifically. Generally, metacognition is thinking of thinking. While specifically, Peirce quotes the definition of metacognition by Taylor, which states that metacognition is the appreciation of what has known which relates to the ability to make a right conclusion about how to apply someone's strategy knowledge of certain situation, and to do it efficiently and accurately. Taccasu (2008) describes metacognition as a part of planning, monitoring and evaluating the instructional process, thinking what we have known or unknown and control how the instruction include both awareness and aware control someone's learn so that it is effective. Mokos and Kafoussi (2013) states that metacognition is someone ability to observe and control him/her-self toward the case known. During the mathematical instruction, the important thing is the process of the study of student's metacognition in doing the problem more focused to the problem solving field relates to mathematics.

Based on some definition stated above, we can identify the main meanings of metacognition: (1) is soul ability in cognition group, (2) is ability to aware, know, cognition process happened in oneself, is ability to direct cognition process in oneself, (3) is an ability of how the instruction done including the process of planning, observing, and evaluation, (4) is an activity of high level thinking activity for its activity can control thinking process happened in oneself in the present time, and (5) relates to student's thinking process to find out suitable strategy in solving problem, (6) metacognition skill is very important in solving mathematical problem, so the skill needs to improve. To improve metacognition skill, student needs awareness in his/her thinking steps. Student awareness in thinking is needed to finish a problem.

\subsection{The Components of Metacognition}

Magiera and Zawojewski (2011) find that metacognition activity happened during giving assignment in the class. Metacognition happening in the students has three components, e.g. awareness, evaluation, and regulation. During the process of metacognition, it can be seen the appearing activities in every components of metacognition called as types of metacognition activities. The types of awareness consist of what the students know, what the students need to solve the problem, what the students must do, where the students solve the problem. The types of evaluation consist of result evaluation, students' difficulty problem of evaluation, progress, ability or understanding. The types of regulation consist of planning strategy, selecting strategy of problem solving, formulating the goal.

Awareness, according to Wilson and Clarke (2002, 2004), relates to someone's awareness in the process of learning or in the process of solving problem, the content of specific knowledge owned, and someone's knowledge in learning or strategy in solving problem. It also includes someone's knowledge about what is needed to do, and what has done, and what can be done in a certain learning or situation in solving the problem. Evaluation refers to evaluation made by someone about thinking process, ability and limitation, such as working in a certain situation or as a self-complication. For example, someone can make evaluation about thinking effectiveness done or strategy chosen. Regulation in metacognition happens when someone uses his/her skill of metacognition to direct knowledge and thought and refers to individual knowledge in the form of strategy, such as how and why using certain strategies, as well as skill, such as planning, self-correction, decide the goal to optimal the usage of their own cognition source.

Metacognition components stated by Wilson and Clarke (2002, 2004) and Magiera and Zawojewski (2011) have indicators as variable and measurement. However, how the process of changes among the components of metacognition has not analysed deeper yet. Sriraman (2003) has considered students about the relationship between their knowledge and what is needed in problem situation given, as Stillman and Gabraith (1998). 
Evaluation has been described and studied concerning the students explicit reflection during the process of solving problem, the function of evaluation in determining the strategy in solving problem. Make a decision in systematic evaluation, alternative plan, and strategy in solving problem (Lester, 1980; Garofalo \& Kroll, 1989). Regulation has been clarified in the form of student flexibility in choosing a solution plan, choosing strategy, and plan implementation improved by Lester (1989), Zan (2000).

\section{Method}

The study is a descriptive qualitative research so that the method used in the study methods and analysis of qualitative data. To obtain research data, researcher undertook some steps as follows: (1) gave to the subject matter of research as many as 23 students who have taken mathematics courses differential calculus. Problems were given as a matter of application of the derivative function of the variable to determine the maximum area of a field. Problem has been validated by the mathematician; (2) the subject of research resolved the matter in the think-aloud for 60 minutes. Researcher corrected students' works to classify them into categories of students capable of high, medium, and low. Think-aloud activity recorded in the form of video footage to be observed metacognition process; (3) once the subjects solved the problem, researcher gave questionnaires metacognition form of 14 statements about metacognition and every statement given alternatives replied "yes", "no" or "unsure". Statement in the questionnaire consisted of 6 statements related to the process of awareness, 5 statements related to the evaluation process, and the 3 statements related to the regulation process. If the study subjects answered "yes", it meant that the indicator component of metacognition would appear, if did not mean metacognition, indicator would not appear, and when the subject answered "unsure" followed up with interviews; (4) researcher studied the video footage and recorded the results in the observation sheet which included the indicators and descriptors awareness, evaluation, and regulation. In the awareness process observation sheet contained 5 indicators with 30 dekriptors, evaluation contain 5 indicators with 23 descriptors, and regulation contained 4 indicators with 19 descriptors; (5) conducted interviews, interviews aimed to explore the emergence of indicators and descriptors awareness, evaluation, and regulation; (6) transcription research data. Transcription was made after researcher get the data needed in the research. Transcripts of data in the study was the transcript of the think-aloud and interview transcripts; (7) performed data reduction. Data reduction was done by making abstractions core summarizing data, processes and statements that needed to be maintained to remain in it. Compiled data in units which was further categorized by making the code; (8) data analysis, process analysis metacognition each research subject was through each of the indicators awareness, evaluation, and regulation. Analysis was conducted to describe the activity of thinking the subject of research in accordance with the indicators and descriptors in every process of awareness, evaluation, and regulation; (9) data validation, data validation was done by triangulation techniques and inspection peers through discussion and research seminar; (10) summed up the results of the study. Conclusions obtained through a comparison between the works of the students, metacognition questionnaire, think-aloud transcripts, observation using observation sheets, and a transcript of the interview each subject of study.

\section{Results}

The data of the study are in the form of the result of works, the transcript of think-aloud, result of the observation using observation sheet, answers of metacognition questionnaire and the interview transcript were studied and analysed qualitatively. The theory design built by the researcher was analysing the characteristic of the student metacognition process in finishing calculus problems through indicators of awareness, evaluation, and regulation. Based on the theory design, the result of analyse of the study was grouped into category of characteristic of student metacognition process of high, middle and low ability.

The result of the study is from 23 students of Mathematics Education Department who had Differential Calculus. They were given calculus problems and during finishing it, the components of awareness, evaluation, and regulation appeared. Besides the metacognition appearance components completely, the subject of the study were given similar patterns so the next analyse was to classify the subjects into high, middle, and low ability. Based on it, 23 subjects of the study were classified into 6 for high ability, 9 for middle ability, and 8 for low ability.

Based on the result of data analyse using the method of constant comparison by Glaser and Strauss and data validation using triangulation in which each of the subject of the study in each group had relatively same characteristic. So that data explanation was done to 6 subject of the study. They were S-1 and S-2 of high ability group, S-3 and S-4 of middle ability group, and S-5 and S-6 of low ability group. The next step was studying the characteristic of metacognition process of those three groups of subject of the study through their component indicators of awareness, evaluation, and regulation. 
The component of awareness had 5 indicators. They were the subject of the study rethought of what known about calculus problem given (A1), rethought of the calculus questions and match with similar problem which obtained and finished before. (A2), rethought of cases which have not been solved before (A3), rethought of the next step to do to finish calculus problem given (A4), and rethought of steps done when answering calculus problem (A5).

The component of evaluation had 5 indicators. They were the subject of the study rethought the way used to finish calculus problem given, (E1), rethought of the order and steps to do when finishing calculus problem given (E2), recheck the result of answers of calculus problem finished (E4), and rethought failure done in answering calculus problem given using previous way (E5).

The component of regulation had 4 indicators. They were the subject of the study rethought and made a plan to finish calculus problem given soon (R1), rethought the different way used in answering calculus problem given (R2), rethought of what will be done next after finishing calculus problem (R3), and rethought how to change the way in finishing calculus problem given (R4).

The process of happening of metacognition of the subject of the study and their characteristics can be explained as follows.

\subsection{The Process of High Ability Student's Metacognition}

The subject of the study S-1 and S-2 have relatively same metacognition process characteristic. During metacognition process, S-1 and S-2 show the activity which describes the characteristic of the component indicators of awareness, evaluation, and regulation. When finishing calculus problems, the indicators appear in order A1, A2, A3, A4, A5, E1, E2, E3, E4, E5, R1, R2, R3, and R4.

The explanation of each descriptor and the appearance of indicators S-1 and S-2 can be seen in Figure 1.

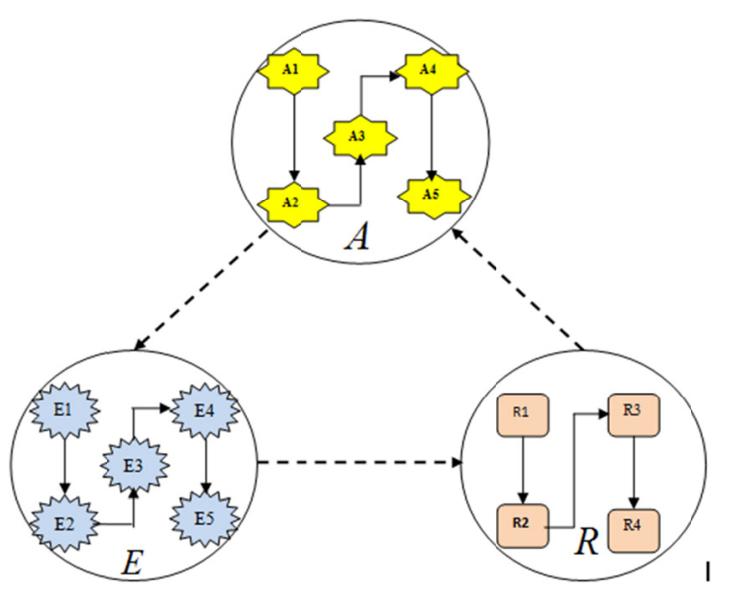

Figure 1. Metacognition Process S-1 and S-2

Note. A is awareness process, $\mathrm{E}$ is evaluation process, and $\mathrm{R}$ is regulation process

\subsection{The Process of Middle Ability Student's Metacognition}

The middle ability subject of the study, S-3 and S-4 carried out metacognition process with complete indicators but disorder. When finishing the problems, the indicator in S-3 appeared in order A1, A2, A3, A5, A4, E2, E1, E3, E4, E5, R1, R3, R2, and R4. The indicator in S-4 appeared in order A1, A2, A3, A4, A5, E1, E2, E3, E4, E5, R1, $\mathrm{R} 2, \mathrm{R} 4, \mathrm{R} 3$.

The order of appearing indicator in S-3 can be seen in figure 2 and the order of appearing indicator in S-4 can be seen in Figure 3. 


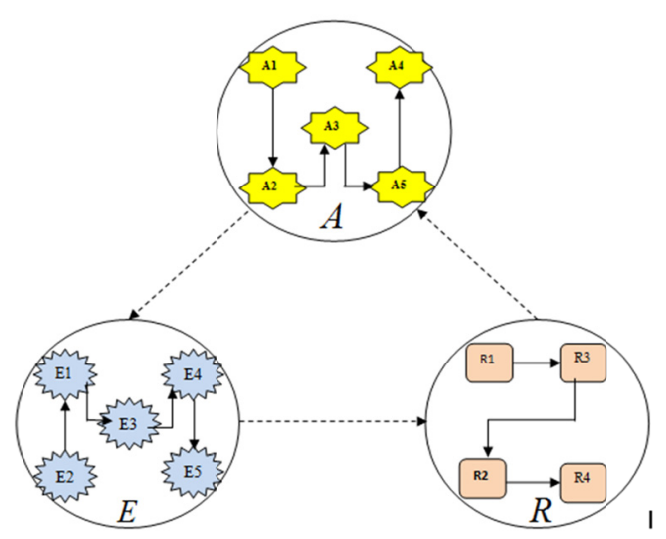

Figure 2. Metacognition Process S-3

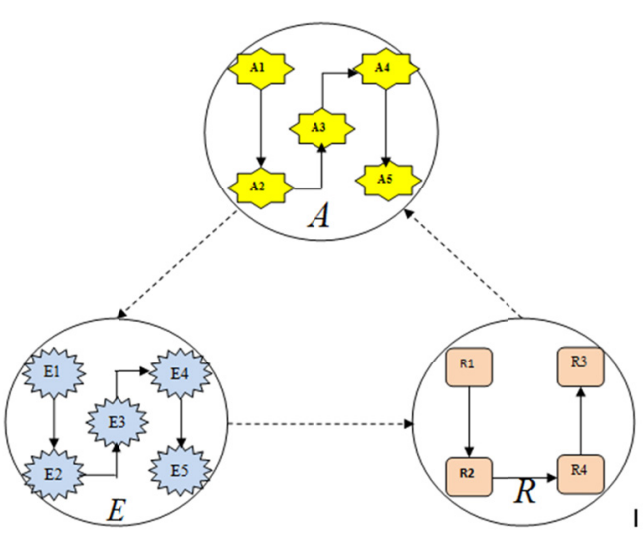

Figure 3 Metacognition Process S-4

Note. A is awareness process, $\mathrm{E}$ is evaluation process, and $\mathrm{R}$ is regulation process

\subsection{The Process of Low Ability Student's Metacognition}

The low ability subjects of the study are S-5 and S-6. The change of metacognition process S-5 and S-6 show the activity which describes the characteristic of indicators awareness, evaluation, and regulation. When finishing calculus problem, the indicator S-5 appears in order A1, A3, A2, A4, A5, E1, E2, E3, E4, R1, R3, R2, and R4. The indicator S-6 appears in order A1, A2, A3, A4, E1, E2, E3, E4, E5, R1, R2, R4, and R3.

The order of appearing indicator in S-5 can be seen in figure 4 and the order of appearing indicator in S- 6 can be seen in Figure 5.

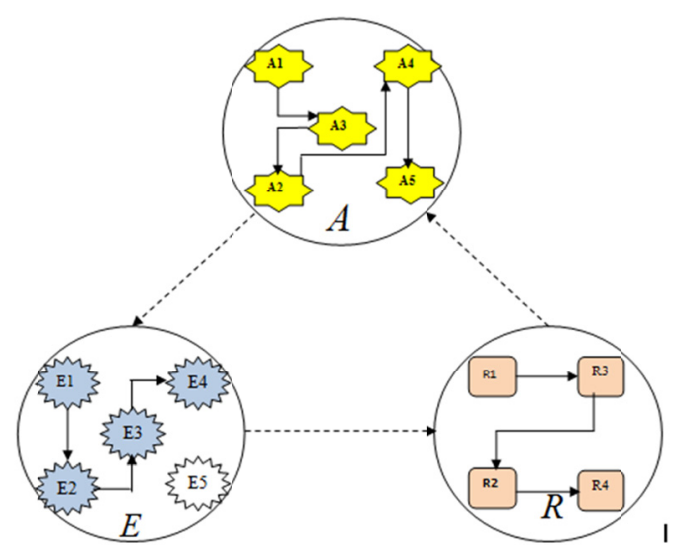

Figure 4. Metacognition Process S-5

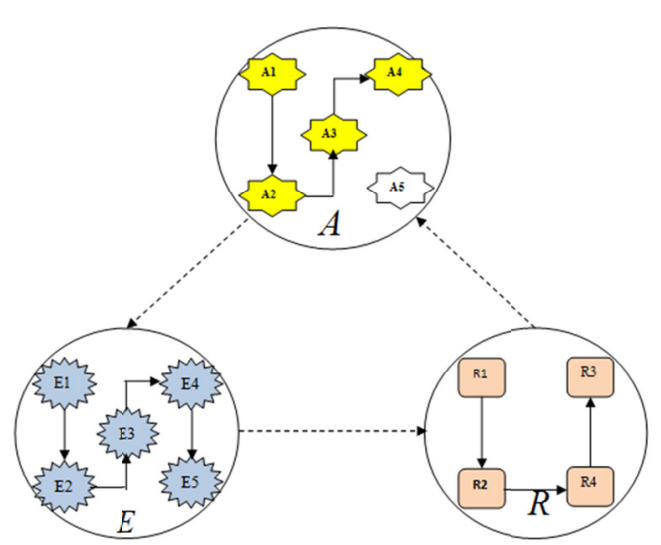

Figure 5 Metacognition Process S-6

Note. A is awareness process, $\mathrm{E}$ is evaluation process, and $\mathrm{R}$ is regulation process

The finding of the result of the study above can be related to the previous theory as the basic of the study done. If being related to Wilson and Clarke's $(2002,2004)$ opinions, each of the characteristic of each components are activities relating to someone's ability to be able to think what have been done when finishing the problem. The problem of the study is how the subject of the study can find out a believed step as the answer of calculus problem given. The belief of the subject of the study is based on the process of evaluation and regulation done and as part of abilities to observe her/him-self toward a case known, self-control can be done when finishing problem (Mokos \& Kafoussi, 2013). Concerning to the indicator during the process of metacognition, it can be seen that activity as types of metacognition activity. The types of awareness activities are what are known by student, what is needed by the student to solve the problem, what must be done by the student, where the student is when finishing the problem. The types of evaluation activities are evaluation of the result, evaluation of the problem, student's difficulty, the evaluation of the progress, ability or understanding. The types of regulation are the strategy in planning, choosing strategy in solving problem, formulating the goal (Magiera \& Zawojewski, 
2011).

\section{Conclusion}

Based on the data analyse, it can be concluded that the high ability student metacognition process characteristic in solving calculus problem is complete and in order, the middle ability student is complete but disorder, and the low ability student is incomplete.

The characteristic of complete and in order metacognition process is in S-1 can be explained as follows: The component of awareness with A1 brings up 6 characteristics, A2 brings up 7 characteristics, A3 brings up 4 characteristics, A4 brings up 8 characteristics A5 brings up 1 characteristic. The component of evaluation with the indicator E1 brings up 2 characteristics, E2 brings up 5characteristics, E3 brings up 6 characteristics, E4 brings up 4 characteristics, and E5 brings up 4 characteristics. The component of regulation with the indicator R1 brings up 3 characteristics, R2 brings up 3 characteristics, R3 brings up 3 characteristics, and R4 brings up 5 characteristics.

The characteristic of complete and in order metacognition process is in S-2 can be explained as follows: The component of awareness with A1 brings up 4 characteristics, A2 brings up 7 characteristics, A3 brings up 4 characteristics, A4 brings up 8 characteristics A5 brings up 1 characteristic. The component of evaluation with the indicator E1 brings up 3 characteristics, E2 brings up 3 characteristics, E3 brings up 6 characteristics, E4 brings up 4 characteristics, and E5 brings up 4 characteristics. The component of regulation with the indicator R1 brings up 3 characteristics, R2 brings up 3 characteristics, R3 brings up 3 characteristics, and R4 brings up 5 characteristics.

The characteristic of complete but disorder metacognition process is in S-3 can be explained as follows: The component of awareness with A1 brings up 5 characteristics, A2 brings up 5 characteristics, A3 brings up 4 characteristics, A4 brings up 6 characteristics A5 brings up 1 characteristic. The component of evaluation with the indicator E1 brings up 2 characteristics, E2 brings up 4 characteristics, E3 brings up 5 characteristics, E4 brings up 3 characteristics, and E5 brings up 3 characteristics. The component of regulation with the indicator R1 brings up 2 characteristics, R2 brings up 2 characteristics, R3 brings up 2 characteristics, and R4 brings up 4 characteristics

The characteristic of complete but disorder metacognition process is in S-4 can be explained as follows: The component of awareness with A1 brings up 4 characteristics, A2 brings up 6 characteristics, A3 brings up 4 characteristics, A4 brings up 7 characteristics A5 brings up 1 characteristic. The component of evaluation with the indicator E1 brings up 2 characteristics, E2 brings up 4 characteristics, E3 brings up 5 characteristics, E4 brings up 3 characteristics, and E5 brings up 2 characteristics. The component of regulation with the indicator R1 brings up 2 characteristics, R2 brings up 3 characteristics, R3 brings up 1 characteristic, and R4 brings up 4 characteristics

The characteristic of uncomplete metacognition process is in S-5 can be explained as follows: The component of awareness with A1 brings up 5 characteristics, A2 brings up 3 characteristics, A3 brings up 4 characteristics, A4 brings up 5 characteristics A5 brings up 1 characteristic. The component of evaluation with the indicator E1 brings up 2 characteristics, E2 brings up 3 characteristics, E3 brings up 4 characteristics, E4 brings up 3 characteristics, and $\mathrm{E} 5$ brings up 0 characteristic. The component of regulation with the indicator R1 brings up 3 characteristics, R2 brings up 3 characteristics, R3 brings up 3 characteristics, and R4 brings up 3 characteristics

The characteristic of uncomplete metacognition process is in S- 6 can be explained as follows: The component of awareness with A1 brings up 4 characteristics, A2 brings up 4 characteristics, A3 brings up 5 characteristics, A4 brings up 5 characteristics A5 brings up 0 characteristic. The component of evaluation with the indicator E1 brings up 2 characteristics, E2 brings up 4 characteristics, E3 brings up 5 characteristics, E4 brings up 2 characteristics, and E5 brings up 2 characteristics. The component of regulation with the indicator R1 brings up 2 characteristics, R2 brings up 2 characteristics, R3 brings up 3 characteristics, and R4 brings up 2 characteristics

The whole characteristics which appearing at each of the subject of the study can be explained in the following Table 1. 
Table 1. The finding of indicator and characteristic of metacognition process

\begin{tabular}{|c|c|c|}
\hline \multicolumn{3}{|r|}{ Component of Awareness } \\
\hline Title & Indicator & Characteristic \\
\hline \multirow{7}{*}{ A1 } & \multirow{7}{*}{$\begin{array}{l}\text { Rethink of what is known of calculus } \\
\text { problem given. }\end{array}$} & The subject of the study: \\
\hline & & $\begin{array}{l}\text { 1. Read the given problem repeatedly and give marks at the words which are regarded as } \\
\text { the key-words. }\end{array}$ \\
\hline & & $\begin{array}{l}\text { 2. Note the important cases of problems by underlining the words which are regarded as } \\
\text { the key-words. }\end{array}$ \\
\hline & & $\begin{array}{l}\text { 3. Check the figure in the problem and represent the length and width of the figure as } \\
\text { variable } x \text { and } y \text {. }\end{array}$ \\
\hline & & $\begin{array}{l}\text { 4. Read the table of problem and note it as the known case and differentiate the volume } \\
\text { for the field as part of problem known. }\end{array}$ \\
\hline & & $\begin{array}{l}\text { 5. Make an important note and conclude known cases as the requirement to determine } \\
\text { the way of solving the problem given. }\end{array}$ \\
\hline & & $\begin{array}{l}\text { 6. Make a correlation ship between the cases known in the problem and each questions } \\
\text { which will be answered at the problem given }\end{array}$ \\
\hline
\end{tabular}

The subject of the study:

1. Read each question repeatedly and relates them to the previous questions of problems as known cases.

2. Give marks at the words which are regarded as the key-words and each questions and conclude cases asked in problems.

3. Make relationship question (a) in the problem relating to the area of rectangular. The

Rethink the questions of calculus problems and similar problems which are finished before relationship between area (L) and length and width is $L=x y$ or $L=5 x y$ depends on the assumption done for the length and width which are assumed before.

4. Make relationship between the length of available barbed wire (s) on the problem and the fanced stable in the form of equation $s=x+6 y$ or $s=5 x+6 y$ Since the length of barbed wire is 240 meters, there are two equations can be written: $240=x+6 y$ or $240=5 x+6 y$.

5. State the area of rectangular at the problem known as one function consisting of long and wide variable known as area function variable.

6. Change the function of rectangular area on the problem given as one function variable by determining the maximum requirement of a field area.

7. Conclude the cases asked in the problem based the note made.

The subject of the study:

1. Make the relationship between the length of barbed wire and wired stable part as equation $240=x+6 y$ or $240=5 x+6 y$.
Rethink of cases which have not been

finished in the last time yet when finishing calculus problem given.

2. State the area of stable in form of one changer function as $L=x y$ into $L=x(240-6 x)$

3. State the area of stable in the form of one changes function as $L=5 x y$ into $L=5(240-6 y / 5) y$

4. Do the substitution of area function in one changer and determine downward (derivative) of the function.

5. Write downward of one changer function and determine the requirement of maximum and minimum value of a function as $d L / d x=0$ or $d L / d y=0$

The Subject of the study:

1. Rewatch cases known in the problem.

2. Chose the way used to do the problem given based on the knowledge got before.

3. Determine variable value decided after downwarding the area function stated in one changer function.

Rethink the next step to do to finish calculus problem given.
4. Do variable substitution which has got into the previous function, i.e. $240=x+6 y$ or $240=5 x+6 y$

5. Find out the whole stable area and each stable as the answer of the problem given.

6. Reread table at the problem given to check the truth of the answers got.

7. Write the area comparison of each stable and the amount of goats.

8. Write the fee of stable building material and the fee of weekly operational as stated in table of problem given. 
The subject of the study:

1. Reread the answers of the problem to make known the order and systimatical answers of problem as being asked and required at the questions (a), (b), and (c).

Rethink the explanation of the answers of calculus problem given
2. Try to use another way to answer the problem which has not done before.

3. Use the new way repeatedly and check the cases known in the problem.

4. Compare the answers explanation between one way and the other which has been done before.

\section{Component of Evaluation}

\begin{tabular}{ll}
\hline Title & Indicator \\
\hline & Rethink the way used to finish calculus \\
E1 problem given,
\end{tabular}

The subject of the study:

1. Compare the result of each way done in answering the questions at the problem given.

2. Mark the important things at the ways and steps used to solve the problem.

3. Note the important cases at the difference between the used to solve the problem given.

4. Make the relationship between cases known and the ways used to finish problem. The subject of the study:

1. Recheck the relationship between the cases known and cases asked in the problem.

2. Check the explanation of the answers written based on in the ways done.

Rethink of the order of steps to do at the time finishing calculus problem given.

3. Recheck the relationship writing between the length of wire available at the problem given and part of the fence which is fenced.

4. Read the table and make an order of the amount of goats in each stable with the area of each stable.

5. Mark the important cases on the steps of answering problem done.

The subject of the study:

1. Check maximum and minimum requirement of one changer function based on the area formula written before.

2. Recount the length and width of the whole stable and each of the stable at the problem given.

Check the answers of calculus problems finished.

3. Recount the comparison between the area of the stable and the amount of goats in each stable.

4. Recount the amount of the building stable material.

5. Recount the operational fee of the whole stables weekly.

6. Conclude question answers thoroughly.

The subject of the study:

1. Reread the question answers (a), (b), and (c) to make known whether the answers written on the answer sheet are right or not.

Rethink of the truth of the calculus answers available.

2. Make a relationship between answers obtained and each problem given.

3. Correct the length and width of the stable obtained with the length of the wire available.

4. Recount problem (b) and (c) by rewatch table 1 on the calculus problem.

The subject of the study:

1. Reread the answers of each of the question to know the truth value.

2. Recheck the answers about the requirement fulfilled maximum and minimum value of the area of whole stable in the question (a)

E5 calculus problem given by previous way.

3. Recheck question answers (b) about comparison between the amount of stable and the area of the stable as the requirement at figure (1) and table (1) on calculus problem.

4. Recheck the answers (c) about total operational fee each week and stable building fee as being required on table (1) on the calculus problem.

Component of Regulation

Title Indicator

The subject of the study:

1. Recheck the problem answer repeatedly before making conclusion.

2. Decide the proper and easy way to answer problem questions given

3. Order the answers of each questions based on the requirement known before.

4. Mark the failure in counting the problem answers given.

5. Reread table and figure in the problem given to determine the easy and proper way used to answer the problem given. 


\begin{tabular}{|c|c|c|}
\hline R2 & $\begin{array}{l}\text { Rethink different way used to answer } \\
\text { calculus problem given. }\end{array}$ & $\begin{array}{l}\text { The subject of the study: } \\
\text { 1. Check the way used to answer the problem question. } \\
\text { 2. Differentiate the way used to finish calculus in problem given. } \\
\text { 3. Order question answers of each question in the problem given. } \\
\text { 4. Use the easy way in answering questions to explain the answers of each problem. }\end{array}$ \\
\hline R3 & $\begin{array}{l}\text { Rethink of what will do to start } \\
\text { answering calculus problem. }\end{array}$ & $\begin{array}{l}\text { The subject of the study: } \\
\text { 1. Reread the known cases in the problem given. } \\
\text { 2. Check the accountability of data at the table and figure with the answers given in the } \\
\text { problem given. } \\
\text { 3. Determine and decide the easy way which can be used to answer the problem given. } \\
\text { 4. Determine the answer problem question by making relationship between the known } \\
\text { cases and asked. }\end{array}$ \\
\hline R4 & $\begin{array}{l}\text { Rethink how to change the way in } \\
\text { finishing calculus problem given. }\end{array}$ & $\begin{array}{l}\text { The subject of the study: } \\
\text { 1. Recheck the answers of problem questions given and compare the questions to } \\
\text { rectangular figure known. } \\
\text { 2. Mark the important cases of the answers known. } \\
\text { 3. Make a conclusion at the answers using the way done. } \\
\text { 4. Check the answer difficulty level done. } \\
\text { 5. Recheck the answers of the problems given at answer sheet of the subject of the study. } \\
\text { 6. Conclude each question answer (a), (b), and (c) of questions given. }\end{array}$ \\
\hline
\end{tabular}

\section{References}

Anderson, L. W., \& Krathwohl, D. R. (2001). A Taxonomy for learning, teaching, and assessing (A Revision of Bloom 's taxonomy of educational objectives). New York: Addision Wesley Longman, Inc.

Baker, L., \& Brown, A. L. (1984). Metacognitive skills and reading. In J. H. Douglas, J. Dunlosky, \& A. C. Graesser (Eds.), Handbook of metacognition in education (pp. 7-25). New York: Routledge.

Biryukov, P. (2003). Metacognitive aspects of solving combinatorics problem Kaye College of Education. Retrieved February 13th, 2014, from https://www.cimt.plymouth.ac.uk

Cromley, J. G. (2005). Metacognition, cognitive strategy instruction, and reading in adult literacy. Retrieved March 1st, 2014, from https://www.ncsall.net

Davidson, J. E. \& Sternberg, R. J. (1998). Smart problem solving: How metacognition helps. In D. J. Hacker., J. Dunlosky, A. C. Graesser (Eds.), Metacognition in educational theory and practice (pp. 47-68). Mahweh, NJ: Lawrence Erlbaum Associates.

Desoete, A., Roeyers, H., \& Buysse, A. (2001). Metacognition and mathematical problem solving in Grade 3. Journal of Learning Disabilities, 34(5), 435.

Djamarah, S. B. (2008). Psikologi belajar. Jakarta: Rineka Cipta

Duffin, J. M., \& Simpson, A. P. (2000). A Search for Understanding. Journal of Mathematical Behavior, 18(4), 415-427. https://doi.org/10.1016/S0732-3123(00)00028-6

Efklides, A. (2005). Metacognition and affect: What can metacognitive experiences tell Us about the learning process?

Flavell, J. (1976). Metacognitive aspects of problem solving. In L. Resnick (Ed.), In the nature of intelligence.

Friedrichs, A. G., \& Hoyt, J. D. (1970). Developmental changes in memorization processes. Cognitive Psychology, 1, 324-340. https://doi.org/10.1016/0010-0285(70)90019-8

Garofalo, J., \& Lester, F. K. (1985). Metacognition, cognitive monitoring, and mathematical performance. Journal for Research in Mathematics Education, 16, 163-176. https://doi.org/10.2307/748391

Goos, M., Galbraith, P., \& Renshaw, P. (2002). Socially mediated metacognition: Creating collaborative zones of proximal development in small group problem solving. Educational Studies in Mathematics, 49(2), 193-223. https://doi.org/10.1023/A:1016209010120

Hudojo, H. (1988). Mengajar belajar matematika. Jakarta: Departemen Pendidikan dan Kebudayaan.

In'am, A., Sa'ad, N., \& Ghani, S. A. (2012). A Metacognitive approach to solving Algebra problems. International Journal of Independent Research and Studies, 1(4), 162-173. University Pendidikan Sultan 
Idris, Malaysia.

Karan, E. P., \& Irizarry, J. (2011). Effects of Metacognitive Strategies on Problem Solving Ability in Construction Education.

Kuzle, A. (2011). Patterns of metacognitive behaviour during mathematics problem solving in a dynamic geometry environment. (Online).Volume 8, Number 1, January 2013, (www.jwilson.coe.uga.edu), accessed on September 20th, 2014.

Lesh, R., \& Zawojewski, J. S. (2007). Problem solving and modeling. In F. Lester (Ed.), The handbook of research on mathematics teaching and learning (2nd ed., pp. 763-804). Reston, VA/Charlotte, NC: National Council of Teachers of Mathematics.

Lioe, L. T., Ho, K. F., \& Hedberg. (2006). Students' metacognitive problem solving strategies in solving open-ended problems in pairs.

Livingstone, J. L. (1997). Metacognition: An Overview.

Magiera, M. T., \& Zawojewski, J. S. (2011). Characterizations of social-based and self-based contexts associated with students' awareness, evaluation, and regulation of their thinking during small-group mathematical modeling. Journal for Research in Mathematics Education, 42(5), 486-516. https://doi.org/10.5951/jresematheduc.42.5.0486

Mariam, A. M., \& Idrus, N. M. (2014). Metacognitive strategies in quadratic equation word problem. Jurnal Pendidikan Sains dan Matematik Malaysia, 3(2).

Matlin, M. W. (1998). Cognition. Philadelphia: Harcourt Brace College Publisher.

Mokos, E., \& Kafoussi, S. (2013). Elementary students' spontaneous metacognitive functions different types of mathematical problems. Journal Research in Mathematics Education, 2(2), 242-267.

Molenaar, I., van Boxtel, C. A. M., \& Sleegers, P. J. C. (2011). Metacognitive Scaffolding in an Innovative Learning Arrangement.

Moleong, L. J. (2008). Metode penelitian kualitatif. Bandung: PT Remaja Rosda Karya.

Panaoura, A., Gagatsis, A., \& Dimetriou, A. (2009). An Intervention to the metacognitive performance: Self-Regulation In mathematics and mathematical modeling. Acta Didactica Universitatis Comenianae Mathematics, 9, 63-79.

Polya, G. (1988). How to solve It, A New aspect of mathematical method. Oxford: Princeton University Press Princeton and Oxford.

Praba, G. J. (2013). Metacognitive instruction and cooperative learning strategi for promoting insightful learning in science. International Journal on New Trends in Education and Their Implications, 4(1).

Purnomo, D. (2014a). Proses metakognisi matematis siswa dalam pemecahan masalah. Paper presented in Mathematics Education National Seminar in Ronggolawe University. Tuban, May 24th, 2014.

Purnomo, D. (2014b). Profil metakognisi siswa kelas 3 Sekolah Dasar pada pemecahan masalah bangun datar berdasar kerja kelompok. Paper presented in National Seminar of Educational in Kanjuruhan Malang University, June 14th, 2014.

Purnomo, D. (2014c). Proses metakognisi siswa Sekolah Dasar pada pemecahan masalah dalam kelompok kecil. Paper presented in Mathematics Nastional Conference XII in Institut Teknologi Sepuluh Nopember (ITS). Surabaya, June 11st-13rd, 2014.

Purnomo, D. (2014d). Proses metakognisi pada kelompok kecil siswa kelas III Sekolah Dasar dalam memahami konsep bangun datar. Paper presented in Mathematics Education National in Sanata Dharma University Jogjakarta, September 13rd, 2014.

Schoenfeld. (1994). Mathematical thinking and problem solving. New Jersey: School Mathematics. Reston: NCTM

Sengul, S., \& Katranci, Y. (2012). Metacognitive Aspects of Solving Function Problems. Procedia-Social and Behavioral Sciences, 46, 2178-2182.

Soedjadi, R. (2000). Nuansa kurikulum matematika sekolah di Indonesia. Dalam Majalah Ilmiah Himpunan Matematika Indonesia. Prosiding Konferensi Nasional Matematika X ITB, July 17th-20th, 2000).

Tan O. S., Parsons, R. D., Hinson, S. L., \& Sardo-Brown, D. (2003). Educational psychology a 
practitioner-researcher Approach. Australia: Thomson.

Veenam, M. V. J., Wilhelm, P., \& Beishuize, J. J. (2004). The Relation between intellectual and metacognitive skills from a developmental perspective.

Wellman, H. M. (1985). Origins of Metacognition. In D. L. F. Pressley, G. E. McKinnon, \& T. G. Waller (Eds.), Metacognition, cognition and human performance (Volume 1). Orlando, Florida: Academic Press.

Wilson, J., \& Clarke, D. (2002). Monitoring mathematical metacognition. Paper presented at the Annual Meeting for the American Education Research Association, New Orleans, LA.

Wilson, J., \& Clarke, D. (2004). Towards the modelling of mathematical metacognition. Mathematics Education Research Journal, 16(2), 25-48.

Zaenal, Z., \& Tajudin, N. M. (2013). Metacognitive process in solving non-routine mathematics problems.

Zechmeister, E. B., \& Neyberg, S. E. (1982). Human memory: An Introduction to research and theory. Monterey, CA: Brok/Cole Publishing Company.

\section{Appendix A}

\section{Calculus Problem}

Mr. Syarif has 100 goats. They will be entered into indentical rectangular stable as Figure 1 and the amount of each stable as written in Table 1.

\section{RICE STOREHOUSE}

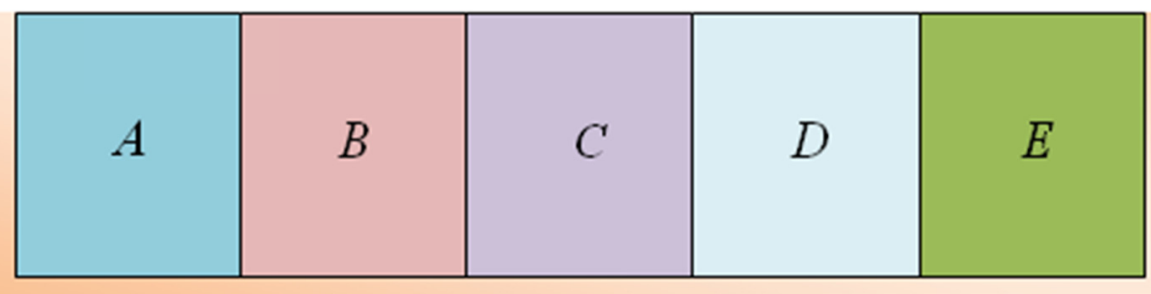

Figure A1. Sketch of Mr. Syarif's Stable

Mr. Syarif's stable lies behind rice storehouse owned by a businessman. It will be fenced with barbed wire to guard his goats.

Because being behind a rice storehouse, the part which is bordered with rice storehouse doesn't need to fence. Mr.Syarif prepares 240 meters barbed wire to fence his stable.

Entering goats into the stable, Mr. Syarif makes a note as follows:

Table A1. Comparison and Content of Mr. Syarif Stable

\begin{tabular}{|l|c|c|c|c|}
\hline & Stable A & Stable B & Stable C & Stable D \\
\hline Amount of goats & 20 & 24 & 25 & 16 \\
\hline $\begin{array}{l}\text { Fee of stable } \\
\text { material }\end{array}$ & Rp.500.000,- & Rp.500.000,- & Rp.500.000,- & Rp.500.000,- \\
\hline $\begin{array}{l}\text { Fee of goat daily } \\
\text { operational of each } \\
\text { stable }\end{array}$ & Rp.150.000,- & Rp. $160.000,-$ & Rp. $165.000,-$ & Rp. $.145 .000,-$ \\
\hline
\end{tabular}

Do the following problems based on the text above! 
a. Measure Mr.Syarif's stable to make all stables as wide as possible!

b. State the comparation between the amount of goat in each stable and the width of each of stable!

c. Count the fee of weekly operational needed by Mr.Syarif and the fee of the whole stable!

(Adapted and modified from the Book of Calculus volume I by Edwin J. Purcell, Dale Verberg, dan Steven E, Rigdon in 2004 page 172).

\section{Apendix B}

\section{The Questionnare}

Put a cross $(X)$ in the column alternatives according to your choice

\begin{tabular}{|c|c|c|c|c|}
\hline \multirow{2}{*}{ No } & \multirow{2}{*}{ Statement } & \multicolumn{3}{|c|}{ Alternative } \\
\hline & & Yes & No & Unsure \\
\hline 1. & I read the problem more than once & & & \\
\hline 2. & I checked that I understood what the problem was asking me & & & \\
\hline 3. & I assessed how much time I need to solve this problem & & & \\
\hline 4. & I represented the problem schematically & & & \\
\hline 5. & $\begin{array}{l}\text { I tried to remember whether I had worked on the problem like this } \\
\text { before }\end{array}$ & & & \\
\hline 6. & I've built a strategy for solving the problem & & & \\
\hline 7. & I did not know how to begin & & & \\
\hline 8. & $\begin{array}{l}\text { During solving the problem I encountered a difficulty (if "Yes", } \\
\text { describe the character of the difficulty) }\end{array}$ & & & \\
\hline 9. & $\begin{array}{l}\text { During solving the problem I found a mistake and corrected it (if } \\
\text { "Yes", describe the mistake) }\end{array}$ & & & \\
\hline 10. & I thought about how I was going & & & \\
\hline 11. & I tried different approaches for solving the problem & & & \\
\hline 12. & I asked myself whether my answer made sense & & & \\
\hline 13. & I checked my calculations to make sure they were correct & & & \\
\hline 14. & $\begin{array}{l}\text { I thought whether there was something in the information that was } \\
\text { given in the problem that needed special attention (if "Yes", describe } \\
\text { it) }\end{array}$ & & & \\
\hline
\end{tabular}

\section{Copyrights}

Copyright for this article is retained by the author(s), with first publication rights granted to the journal.

This is an open-access article distributed under the terms and conditions of the Creative Commons Attribution license (http://creativecommons.org/licenses/by/4.0/). 